\title{
Vitamin D Deficiency in Adults with Musculoskeletal Pain
}

\author{
Kas iskelet Sistemi Ağrısı Olan Yetişkinlerde D Vitamini Yetersizliği \\ Sevgi Gümüş Atalay, Roni Atalay*, Berat Meryem Alkan, Fatma Fidan, Sinem Bozkurt, Hatice Aksekili, \\ Özge Ardıçoğlu
}

Yıldırım Beyazıt University Faculty of Medicine, Atatürk Training and Research Hospital, Clinic of Physical Medicine Rehabilitation, Ankara, Turkey *Abdurrahman Yurtaslan Training and Research Hospital, Clinic of Gastroenterology, Ankara, Turkey

\section{Summary}

Objective: The aim of this study was to determine whether vitamin D deficiency in patients with musculoskeletal pain who were admitted to our hospital and to establish the difference between vitamin $\mathrm{D}$ levels according to gender and age groups.

Materials and Methods: Among 28.702 patients, 857 (3\%) patients whose vitamin D levels were studied were included in the study. Serum $25(\mathrm{OH}) \mathrm{D}$ level was determined by liquid chromatography-mass spectrometry (LC-MS). The patients were divided into three groups according to 25(OH) D level as; Group 1: $>30 \mu \mathrm{g} / \mathrm{L}$ (sufficient), group 2: $10-30 \mu \mathrm{g} / \mathrm{L}$ (moderate insufficient), and group 3: $<10 \mu \mathrm{g} / \mathrm{L}$ (severe insufficient). Results: The mean age of the patients were $49.1 \pm 14.5$ (18-87) years and the mean serum vitamin $D$ levels of patients admitted to our hospital were found $15.3 \pm 10.3 \mathrm{\mu g} / \mathrm{L}$. The $25(\mathrm{OH})$ vitamin D levels of $91 \%(780)$ patients were below normal limits. In $44.2 \%(379)$ of the patients, $25(\mathrm{OH}) \mathrm{D}$ level was $<10 \mu \mathrm{g} / \mathrm{L}$ and severe deficiency were found. Vitamin $\mathrm{D}$ levels were lower in females than those in males. Secondary hyperparathyroidism was detected in $17 \%(146)$ of the patients.

Conclusion: Vitamin D deficiency, which is still an important world-wide medical problem despite all preventive measures, is commonly seen in our country and affects especially female population.

Keywords: Vitamin D deficiency, parathyroid hormone, age, gender

\section{Öz}

Amaç: Bu çalışmamızın amacı hastanemize kas iskelet sistemi ağıısı ile başvuran hastalarda D vitamini eksikliği olup olmadığını belirlemek ve yaş ile cinsiyete göre $D$ vitamini düzeyleri arasındaki farkı tespit etmekti.

Gereç ve Yöntem: Çalışmaya 28,702 hastadan D vitamini düzeyi çalışılmış olan toplam 857 (\%3) hasta dahil edildi. Serum 25(OH) D düzeyi likit kromatografi kütle spektrometresi (LK-KS) ile ölçüldü. Hastalar $25(\mathrm{OH}) \mathrm{D}$ vitamini düzeyine göre üç gruba ayrıldı. Grup 1: $>30 \mu \mathrm{g} / \mathrm{L}$ (yeterli), grup 2: 10-30 $\mu \mathrm{g} / \mathrm{L}$ (ılımlı yetersiz) ve grup 3: $<10 \mu \mathrm{g} / \mathrm{L}$ (şiddetli yetersiz) yer aldı.

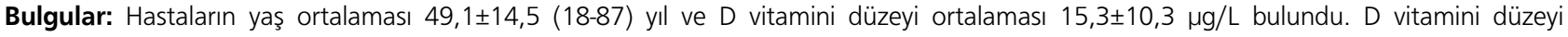
hastaların \%91'inde (780) normalin altındaydı. Hastaların \%44,2'sinde (379) şiddetli yetersizlik tespit edildi ve $25(\mathrm{OH}) \mathrm{D}$ düzeyi $<10 \mu \mathrm{gg} / \mathrm{L}$ 'nin altıdaydı. D vitamini düzeyleri kadınlarda erkeklerden daha düşüktü. Sekonder hiperparatiroidi \%17 (146) hastada gözlendi.

Sonuç: D vitamini eksikliği alınan tüm koruyucu önlemlere rağmen dünya çapında önemli bir sağlık problemidir, ülkemizde yaygın olarak görülür ve özellikle kadınları etkiler.

Anahtar kelimeler: D vitamini eksikliği, paratiroid hormon, yaş, cinsiyet

\section{Introduction}

Vitamin D regulates calcium and phosphorus metabolism via its physiological effects over bowels, kidneys, and parathyroid gland (1-5). Under normal circumstances, $90-95 \%$ of vitamin D present in human body is synthesized in the skin by the effect of sunlight. Vitamin D from food is not of much significance if it is not particularly supplemented. Thus, sunlight is the main source of vitamin $D$, and if it is utilized enough, vitamin $D$ supplements are not required $(6,7) .25(\mathrm{OH}) \mathrm{D}$ is one of the major metabolites of vitamin $D$ in circulation. The reason why $25(\mathrm{OH}) \mathrm{D}$ is measured is that half-life of $25(\mathrm{OH}) \mathrm{D}$ is $2-3$ weeks, whereas that of 1,25-dihydroxy vitamin $D$ is 4-6 hours (8-10). Vitamin $\mathrm{D}$ deficiency is a worldwide common health problem. Vitamin $D$ deficiency and insufficiency affect most of the men and women at all age groups in many geographic regions. This

Address for Correspondence/ Yazışma Adresi: Sevgi Gümüş Atalay MD, Yıldııım Beyazıt University Faculty of Medicine, Atatürk Training and Research Hospital,

Clinic of Physical Medicine Rehabilitation, Ankara, Turkey

Phone: +90 3122532207 E-mail: sevgigumusatalay@hotmail.com Received/Geliș Tarihi: 08.04.2015 Accepted/Kabul Tarihi: 01.07.2015

Turkish Journal of Osteoporosis, published by Galenos Publishing. / Türk Osteoporoz Dergisi, Galenos Yayınevi tarafından basılmıştır. 
situation results from limited exposure to sunlight together with insufficient dietary support containing little calcium intake (11). Vitamin D deficiency causes decline in serum calcium levels by decreasing its absorption from bowels, leading to compensatory parathyroid hormone (PTH) secretion. Thus, secondary hyperparathyroidism causes mobilization of calcium from bone and reduction in bone mineral density (BMD). Despite all preventive measures, vitamin $D$ deficiency leads to medical problems in many countries, especially in elderly (12-14). Deficiency of vitamin $D$ has been reported in patients with many types of musculoskeletal pain (15). Muscle weakness in severe vitamin $D$ deficiency could also be caused by secondary hyperparathyroidism and resultant hypophosphatemia $(16,17)$. The objective of this study was to determine mean vitamin D, calcium, phosphorus, alkaline phosphatase (ALP) and PTH levels of the patients admitting to the outpatient clinic with musculoskeletal pain and to observe differences among gender and factors due to differences in vitamin D levels.

\section{Materials and Methods}

A total of 857 patients with musculoskeletal pain at different regions of skeletal system diagnosed as low back pain, fibromyalgia, artralgia, osteoarthritis, widespread pain, lombar disc herniation, servical disc herniation among 28.702 patients admitted to an outpatient clinic in Atatürk Training and Research Hospital were included in this cross-sectional, retrospective study. Age, gender, vitamin D levels, calcium, phosphorus, ALP and PTH levels were recorded retrospectively from patients' files. 25(OH) D was determined by liquid chromatographymass spectrometry (LC-MS) on an Applied biosystems (USA). Calcium measurements were studied by Roche Cobas c 701 method using a BAPTA (Germany). Phosphorus measurements were studied by Roche Cobas c 701 method using a phosphomolybdate-UV. PTH was determined by Roche Cobas e 601 method using a electrochemiluminescence method (ECLIA). ALP was determined by Roche Cobas c 701 method using PNPP ( $p$-nitro phenylphosphate). Patients were divided into three groups: Vitamin D levels: $>30 \mu \mathrm{g} / \mathrm{L}$ was considered as sufficient, $10-30 \mu \mathrm{g} / \mathrm{L}$ as moderate insufficient, and $<10 \mu \mathrm{g} / \mathrm{L}$ as severe insufficient (14). Parameters that may be relevant were compared with vitamin D levels. PTH levels above $67 \mathrm{pg} / \mathrm{mL}$ were defined as secondary hyperparathyroidism.
Our exclusion criteria included pregnancy or breast feeding at the time of study, sign of rickets, significant renal, hepatic, or thyroid dysfunctions or any other major systemic diseases, including malignancy, diabetes mellitus and metabolic bone diseases.

\section{Statistical Analysis}

Statistical Package for Social Sciences (SPSS) 17.0 software package was used for statistical analysis. In addition to descriptive statistical analysis, comparison between the two groups was performed with Mann-Whitney $U$ test for independent samples and with Spearman correlation analysis for relationship between the parameters. P value $<0.05$ was accepted as statistically significant.

\section{Results}

Retrospective screening showed that $62.9 \%(18,078)$ of the patients admitted to our outpatient clinic were females and $37.1 \%$ (1.0624) were males. A total of 857 patients who were considered to have vitamin $D$ deficiency and checked for serum 25(OH) D, PTH, calcium, phosphorus, and ALP levels were included in the study. Vitamin D levels were checked in $4.2 \%$ (773) of female and $0.9 \%$ (84) of male patients. The mean vitamin $D$ level of the patients was $15.3 \pm 10.3 \mu \mathrm{g} / \mathrm{L}$ and the mean age of the patients was $49.1 \pm 14.5$ (18-87) years. Table 1 shows demographical and laboratory findings of the patients who were considered to have vitamin $D$ deficiency. The mean serum vitamin $D$ level was found to be significantly lower in females than that in males $(p=0.004)$. Table 2 shows $25(\mathrm{OH})$ D, PTH, calcium, phosphorus, and ALP levels of male and female patients. Patients were grouped according to vitamin D levels and gender (Table 3), and it can be clearly seen that

\section{Table 1. Demographical and clinical findings}

\begin{tabular}{|l|l|}
\hline $\mathbf{n}=\mathbf{8 5 7}$ & Mean \pm SD (min-max) \\
\hline Age $($ years $)$ & $49.1 \pm 14.5(18-87)$ \\
\hline $25(\mathrm{OH}) \mathrm{D}(\mu \mathrm{g} / \mathrm{L})$ & $15.3 \pm 10.3(5.3-84)$ \\
\hline Calcium $(\mathrm{mg} / \mathrm{dL})$ & $9.6 \pm 0.5(7.6-15.6)$ \\
\hline Phosphorus $(\mathrm{g} / \mathrm{dL})$ & $3.55 \pm 0.5(1.8-5.7)$ \\
\hline ALP $(\mu \mathrm{g} / \mathrm{L})$ & $77.1 \pm 24.9(31-197)$ \\
\hline Parathormone $(\mathrm{pg} / \mathrm{mL})$ & $54.5 \pm 26.4(9.6-199)$ \\
\hline ALP: Alkaline phosphatase, SD: Standard deviation \\
\hline
\end{tabular}

Table 2. Comparison of demographical and clinical findings according to gender

\begin{tabular}{|l|l|l|l|}
\hline Mean \pm SD $($ min-max) & Female & Male & $\mathbf{p}$ \\
\hline Age $($ years $)$ & $49.5 \pm 14.7(18-87)$ & $45.4 \pm 16.1(20-82)$ & $0.004^{*}$ \\
\hline $25(\mathrm{OH}) \mathrm{D}(\mu \mathrm{g} / \mathrm{L})$ & $15.0 \pm 10.2(5.3-84)$ & $17.3 \pm 11.2(6.6-74.2)$ & $0.004^{*}$ \\
\hline Calcium $(\mathrm{mg} / \mathrm{dL})$ & $9.6 \pm 0.5(7.6-15.6)$ & $9.8 \pm 0.5(8.6-10.8)$ & 0.112 \\
\hline Phosphorus $(\mathrm{mg} / \mathrm{dL})$ & $3.57 \pm 0.5(1.8-5.7)$ & $3.37 \pm 0.5(2.2-4.4)$ & $0.026^{*}$ \\
\hline ALP $(\mu \mathrm{g} / \mathrm{L})$ & $76.9 \pm 25.2(31-197)$ & $79.7 \pm 22.6(42-143)$ & 0.304 \\
\hline Parathormone $(\mathrm{pg} / \mathrm{mL})$ & $55.5 \pm 26.9(9.6-199)$ & $45.9 \pm 19.8(15-132)$ & $0.004^{*}$ \\
\hline ALP: Alkaline phosphatase, SD: Standard deviation & & & \\
\hline
\end{tabular}


$91 \%$ (780) of them were below normal limits. In $44.2 \%$ (379) of these patients, the serum $25(\mathrm{OH})$ D level was $<10 \mu \mathrm{g} / \mathrm{L}$ and severe insufficiency was detected. Severe insufficiency was seen in $47.1 \%$ of the female patients while it was seen in $27.4 \%$ of the male patients who were checked for vitamin $D$ levels. Secondary hyperparathyroidism was detected in 17\% (146) of the patients. There was no significant relationship between vitamin D level and age, calcium, phosphorus, ALP, and PTH levels of the patients $(p>0.05)$.

\section{Discussion}

Vitamin D deficiency should be taken into consideration in the differential diagnosis of patients with musculoskeletal pain and rectify is reported to be an important component in the treatment of these patients (18).

The objective of this study was to determine whether there is vitamin D deficiency in patients with musculoskeletal pain admitted to our hospital and to establish the difference between vitamin D levels according to gender and age groups. Reports from many different countries show that $D$ hypovitaminosis is a world-wide problem and a major health issue $(19,20)$. The usage of different threshold levels in studies complicates the evaluation of vitamin D deficiency and insufficiency. Vitamin D deficiency or insufficiency prevalence changes between $7 \%$ and $80 \%$ depending on the defined threshold (21). When serum $25(\mathrm{OH}) \mathrm{D}$ is higher than $30 \mathrm{ng} /$ $\mathrm{mL}$, the condition is considered as the normal vitamin $D$ level (8-11). In our study, the mean serum $25(\mathrm{OH}) \mathrm{D}$ level of the patients was $15.3 \mathrm{ng} / \mathrm{mL}$, which is very low. In $91 \%$ of the patients included in the study, the vitamin D level was below 30 $\mathrm{ng} / \mathrm{mL}$. In $44.2 \%$ (379) of the patients, the $25(\mathrm{OH}) \mathrm{D}$ level was below $10 \mu \mathrm{g} / \mathrm{L}$ and severe deficiency was detected. Kurt et al. (22) reported that the vitamin D level was below normal limits in $70 \%$ of the patients who were admitted to the osteoporosis clinic, and the mean vitamin D level was $26.13 \pm 18.62 \mu \mathrm{g} / \mathrm{L}$ in their study. Other studies have shown that vitamin $D$ deficiency and insufficiency found in patients with musculoskeletal pain $(23,24)$.

Insufficient vitamin D levels are associated with old age, female gender (25-28). The mean serum vitamin $D$ level was found to be significantly lower in females than in males, while phosphorus and PTH levels were significantly higher in females than in males. Severe insufficiency was seen in $47.1 \%$ of the

\begin{tabular}{|c|c|c|c|}
\hline Vitamin $D(\mu \mathrm{g} / \mathrm{L})$ & $\begin{array}{l}\text { Female } \\
\text { n (\%) }\end{array}$ & $\begin{array}{l}\text { Male } \\
\text { n (\%) }\end{array}$ & $\begin{array}{l}\text { Total } \\
\text { n (\%) }\end{array}$ \\
\hline >30 (sufficient) & $60(7.8)$ & $17(20.2)$ & 77 (9) \\
\hline $\begin{array}{l}10-30 \text { (moderate } \\
\text { insufficient) }\end{array}$ & $357(46.2)$ & $44(52.4)$ & $401(46.8)$ \\
\hline $\begin{array}{l}<10 \text { (severe } \\
\text { insufficient) }\end{array}$ & $356(46.1)$ & $23(27.4)$ & $379(44.2)$ \\
\hline
\end{tabular}

female patients and was seen in $27.4 \%$ of the male patients who were checked for vitamin D levels. Likewise, other studies have also reported vitamin $D$ deficiency being more common in females than in males $(22,29,30)$. In our study, there was no correlation between vitamin $\mathrm{D}$ levels and age.

Vitamin D insufficiency due to decrease in active transport of calcium from bowels leads to reduction in ionized calcium concentration in circulation and increase in PTH secretion. PTH normalizes circulating ionized calcium concentration by mobilizing calcium from skeleton and other target tissues. Rise in PTH increases bone resorption and bone loss. Sahota et al. (31) detected $39 \%$ of vitamin D insufficiency ( $\leq 12 \mathrm{ng} /$ $\mathrm{mL}$ ) prevalence in their study in England, which included 421 osteoporotic postmenopausal women with the mean age of 71.2 years. Secondary hyperparathyroidism was detected in $33 \%$ of the patients with vitamin D insufficiency.

In our study group, severe vitamin D insufficiency was detected in $44.2 \%$ (379) and secondary hyperparathyroidism in $17 \%$ (146) patients. No significant relationship was found between vitamin D levels and age, calcium, phosphorus, ALP, and PTH levels of the patients. Singh et al. (32) found no relationship between serum calcium, albumin, phosphate, ALP levels and vitamin D deficiency in their study. There are studies showing negative correlation between $25(\mathrm{OH})$ D and PTH concentration $(33,34)$. Recent studies reported that vitamin D deficiency is related to musculoskeletal symptoms. The present study had some limitations. First of all, it is a retrospective study, so we did not have any knowledge about the degree of sun exposure and vitamin D intakes of our patients. Another limitation of this study was that we compared vitamin D values of the participants with respect to gender despite the fact that most of them were women. Further studies are needed to investigate the role of vitamin $D$ in patients with musculoskeletal pain.

\section{Conclusion}

Although Turkey is a Mediterranean country, we demonstrated that $25(\mathrm{OH})$ D levels are low in Turkey. In our country, the importance of provision and consumption of vitamin $D$ supported food and utilization of sunlight, especially for the population that is at risk, must be underlined.

\section{Author Contributions}

Ethics Committee Approval: April 2013, Informed Consent: Consent form was filled out by all participants Ankara Atatürk Training and Research Hospital, Concept: Sevgi Gümüş Atalay, Design: Fatma Fidan, Data Collection or Processing: Roni Atalay, Analysis or Interpretation: Berat Meryem Alkan, Literature Search: Sevgi Gümüş Atalay, Writing: Sevgi Gümüş Atalay, Peer-review: External and Internal peer-reviewed, Conflict of Interest: The authors reported no conflict of interest related to this article, Financial Disclosure: The authors declared that this study has received no financial support. 


\section{References}

1. Vogeser M. Quantification of circulating 25-hydroxyvitamin D by liquid chromatography-tandem mass spectrometry. J Steroid Biochem Mol Biol 2010;121:565-73.

2. Moy FM, Bulgiba A. High prevalence of vitamin D insufficiency and its association with obesity and metabolic syndrome among Malay adults in Kuala Lumpur, Malaysia. Public Health 2011;11:735.

3. Tandoğan B, Ulusu NN. Importance of Calcium. Turk J Med Sci 2005;35:197-201.

4. Pehlivan I, Hatun Ş, Aydoğan M, Babaoğlu K, Türker G, Gökalp AS. Maternal serum vitamin $D$ levels in the third trimester of pregnancy. Turk J Med Sci 2002;32:237-41.

5. Karadağ AS, Ertuğrul DT, Tutal E, Akın KO. The role of anemia and vitamin $D$ levels in acute and chronic telogen effluvium. Turk J Med Sci 2011;41:827-33.

6. Atas A, Çakmak A, Soran M. D vitamin metabolizması ve rikets hastalığı. Bakırköy Tıp Dergisi 2008;4:1-7.

7. Özkan B. Rikets. Güncel Pediatri 2007;5:34-41.

8. Vu LH, Whiteman DC, van der Pols JC, Kimlin MG, Neale RE. Serum vitamin D levels in office workers in a subtropical climate. Photochem Photobiol 2011:87:714-20.

9. Nanri A, Foo LH, Nakamura K, Hori A, Poudel-Tandukar K, Matsushita $Y$, et al. Serum 25-hydroxyvitamin D concentrations and season-specific correlates in Japanese aults. J Epidemio 2011:21:346-53

10. Mallah EM, Hamad MF, Elmanaseer MA, Qinna NA, Idkaidek NM, Arafat TA, et al. Plasma concentrations of 25- hydroxvitamin D among Jordanians: Effect of biological and habitual factors on vitamin D status. BMC Clin Pathol 2011;11:8.

11. Kaehler ST, Baumgartner $H$, Jeske $M$, Anliker $M$, Schennach $H$, Marschang $\mathrm{P}$, et al. Prevalence of hypovitaminosis $\mathrm{D}$ and folate deficiency in healthy young female Austrian students in a health care profession. Eur J Nutr 2012;51:1021-31.

12. Thomas MK, Lloyd-Jones DM, Thadhani RI, Shaw AC, Deraska DJ Kitch BT, et al. Hypovitaminosis D in medical inpatients. N Engl J Med 1998;338:777-83.

13. Malabanan A, Veronikis IE, Holick MF. Redefining vitamin D insufficiency. Lancet 1998;351:805-6.

14. Annweiler C, Schott AM, Montero-Odasso M, Berrut G, Fantino $B$, Herrmann FR, et al. Cross-sectional association between serum vitamin $\mathrm{D}$ concentration and walking speed measured at usual and fast pace among older women: The EPIDOS study. J Bone Miner Res 2010;25:1858-66.

15. Holick MF. Resurrection of vitamin D deficiency and rickets. J Clin Invest 2006;116:2062-72

16. Holick MF, Binkley NC, Bischoff-Ferrari HA, Gordon CM, Hanley DA, Heaney RP, et al. Guidelines for preventing and treating vitamin D deficiency and insufficiency revisited. I Clin Endocrinol Metab 2012;97:1153-8.

17. Pfeifer M, Begerow B, Minne HW, Suppan K, FahrleitnerPammer A, Dobnig $\mathrm{H}$. Effects of a long-term vitamin $\mathrm{D}$ and calcium supplementation on falls and parameters of muscle function in community-dwelling older individuals. Osteoporos Int 2009;20:315-22.
18. Heath KM, Elovic EP. Vitamin D deficiency: implications in the rehabilitation setting. Am J Phys Med Rehabil 2006;85:916-23.

19. Iqbal $R$, Khan AH. Possible causes of vitamin D deficiency (VDD) in Pakistani population residing in Pakistan. J Pak Med Assoc 2010:60:1-2.

20. Mithal A, Wahl DA, Bonjour JP, Burckhardt P, Dawson-Hughes B, Eisman JA, et al. Global vitamin D status and determinants of hypovitaminosis D. Osteoporos Int 2009;20:1807-20.

21. Gerdhem P, Ringsberg KA, Obrant KJ, Akesson K. Association between 25-hydroxy vitamin $D$ levels, physical activity, muscle strength and fractures in the prospective population-based OPRA Study of Elderly Women. Osteoporos Int 2005;16:1425-31.

22. Kurt M, Cömertoğlu I, Sarp Ü, Yalçın P, Dinçer G. Osteoporozlu Hastalarda D Vitamini Düzeyleri. Türk Osteoporoz Dergisi 2011;17:68-70

23. Plotnikoff GA, Quigley JM. Prevalence of severe hypovitaminosis $D$ in patients with persistent, nonspecific musculoskeletal pain. Mayo Clin Proc 2003;78:1463-70.

24. Mascarenhas R, Mobarhan S. Hypovitaminosis D induced pain. Nutr Rev 2004;62:354-9.

25. Pérez-López FR, Brincat $M$, Erel CT, Tremollieres F, Gambacciani M, Lambrinoudaki I, et al. EMAS position statement: Vitamin D and postmenopausal health. Maturitas 2012:71:83-8.

26. Gaugris S, Heaney RP, Boonen S, Kurth H, Bentkover JD, Sen SS. Vitamin D inadequacy among post-menopausal women: a systematic review. QJM 2005;98:667-76.

27. Güzel R, Kozanoglu E, Guler-Uysal F, Soyupak S, Sarpel T. Vitamin $D$ status and bone mineral density of veiled and unveiled Turkish women. J Womens Health Gend Based Med 2001:10:765-70.

28. Hicks GE, Shardell M, Miller RR, Bandinelli S, Guralnik J, Cherubini $A$, et al. Associations between vitamin $D$ status and pain in older adults: the Invecchiare in chianti study. J Am Geriatr Soc 2008:56:785-91.

29. Hekimsoy Z, Dinç G, Kafesçiler S, Onur E, Güvenç Y, Pala T, et al. Vitamin $D$ status among adults in the Aegean region of Turkey. BMC Public Health 2010;10:782

30. Jacobs ET, Alberts DS, Foote JA, Green SB, Hollis BW, Yu Z, et al. Vitamin $D$ insufficiency in southern Arizona. Am J Clin Nutr 2008;87:608-13

31. Sahota O, Mundey MK, San P, Godber IM, Lawson N, Hosking DJ. The relationship between vitamin $\mathrm{D}$ and parathyroid hormone: calcium homeostasis, bone turnover, and bone mineral density in postmenopausal women with established osteoporosis. Bone 2004;35:312-9.

32. Singh SK, Manjure $S$, Stott $P$, Shetty A, Iversen SA, Williams CR. Does routine blood bone biochemistry predict vitamin D insufficiency in elderly patients with low-velocity fractures? Journal Orthop Surg (Hong Kong) 2004;12:31-4.

33. Sadat-Ali $\mathrm{M}$, Al -Elg AH, Al-Turki HA, Al-Mulhim FA, Al-Ali AK. Influence of vitamin $D$ levels on bone mineral density and osteoporosis. Ann Saudi Med 2011;31:602-8

34. Dawson-Hughes B. Serum 25-hydroxyvitamin D and functional outcomes in the elderly. Am J Clin Nutr 2008;88:537-40. 